\title{
DEVER AMBIENTAL PROPTER REM E REPONSABILIDADE CIVIL POR DANO AMBIENTAL - DIFERENCIAÇÕES NECESSÁRIAS
}

\author{
PROPTER REM ENVIRONMENTAL DUTY AND ENVIRONMENTAL DAMAGE CIVIL LIABILITY - \\ NECESSARY DIFFERENTIATIONS
}

Eder Augusto Contadin 1

Eduardo Souza ${ }^{2}$

SUMÁRIO: 1. Introdução. 2. Ementa e desenvolvimento do julgado (fundamentação). 3. Inconsistência dogmática da responsabilidade civil ambiental propter rem. 4. Conclusão: $\mathrm{O}$ dever propter rem de recompor a Reserva Legal Florestal. Eliminação do passivo ambiental do imóvel. Responsabilidade civil por danos ambientais que se estabelece perante o anterior titular do direito de propriedade. Incidência do regime jurídico dos deveres propter rem.

\section{INTRODUÇÃO}

$\mathrm{Na}$ jurisprudência brasileira sobre o tema da responsabilidade civil por danos ambientais, identificam-se algumas incoerências dogmáticas, perpetuadas no afã da melhor tutela aos importantes bens ambientais.

Tais incoerências dogmáticas abrangem amplo espectro de consequências com relevância jurídica e social: quebras lógico-sistemáticas ${ }^{3}$, derivadas de falhas conceituais; equívocos

\footnotetext{
${ }^{1}$ Mestre em Direito Civil pela Universidade de São Paulo (Largo de São Francisco). Especialista em direito contratual pela USP (Ribeirão Preto). Advogado. E-mail: edercontadin@hotmail.com

2 Doutorando em Direito Comercial pela Universidade de São Paulo (Largo de São Francisco). Juiz Federal em Vitória/ES. E-mail: eduardofcosouza@hotmail.com

${ }^{3}$ Fenômeno recorrente no argumento jurídico - doutrinário e jurisprudencial - tem sido a utilização dos princípios jurídicos em ordem desestruturante do sistema normativo. Insuficiências metodológicas levam a este fenômeno, em que vária gama de princípios (ou de argumentos lastreados em princípios) encontra aplicação direta na solução de casos concretos, mesmo que desnaturando o plexo normativo (conjunto de regras) incidente na disciplina do caso, ou, ainda, negando-Ihe vigência. Não raras vezes, essas tergiversações metodológicas escudam diretrizes de cunho subjetivo do aplicador. Maior rigor metodológico faz-se crucial diante dessa realidade. Assim, nas lições de Karl Larenz, "Ios princípios no son cabalmente reglas acabadas. Son los
} 
terminológicos; deficiências analíticas (tanto de pressupostos, quanto de eficácia jurídica). Terminam por tornar confuso o entendimento, consolidado ou em construção, de institutos e categorias jurídicas, com prejuízos à segurança jurídica ${ }^{4}$ e à justa aplicação do Direito 5 .

Assim se dá com a caracterização da responsabilidade civil por danos ambientais como uma obrigação propter rem; ou, na mesma linha de consideração, como que o atributo propter rem participaria da natureza - e da estrutura - da responsabilidade civil por danos ambientais ${ }^{6}$.

Assim, como exemplo desse entendimento, recente aresto do STJ, com o seguinte excerto da ementa:

\begin{abstract}
"É firme o entendimento jurisprudencial desta Corte de que a responsabilidade civil dos danos ambientais é objetiva e solidária, além de aderir à propriedade, como obrigação propter rem, o que afeta a todos os agentes que obtiveram proveito da atividade que resultou em dano ambiental" - AgInt no Agravo em Recurso Especial no 1.410.897-5 - MS (2018/0321935-6).
\end{abstract}

Trata-se, como se demonstra, de equívoco de qualificação categorial e de incongruência analítica - estrutural e funcional - do fenômeno jurídico em tela. Responsabilidade civil e obrigações/deveres propter rem são categorias ou institutos jurídicos diversos e de inconciliáveis estruturas, desempenhando, outrossim, funções próprias e apartadas no Ordenamento 7 .

No direito ambiental florestal ${ }^{8}$, tais equívocos metodológicos e dogmáticos afetam notadamente casos concretos que dizem respeito aos deveres de recuperação das Áreas de Preservação Permanente (APP) e de Reserva Florestal Legal (RFL).

fundamentos iniciales de una regulación, que pueden recibir concreción de diferente modo en una regulación intelectualmente fundada en ellos. El principio es sólo el primer paso en la consecución de una regulación, al cual tienen que seguir después otros. El principio no se obtiene mediante la generalización de la regla. Es al revés: hay que hacer una viaje de retorno desde la regulación a los pensamientos de regulación que subyacen bajo ella y desde los cuales la regulación aparece como algo dotado de sentido, y cuando se trata de principios de Derecho justo, como algo justificado. Que en una determinada regulación subyazca un concreto principio es para el jurista una hipótesis de trabajo, que se encuentra confirmada si consigue hallar un pensamiento director al que se puedan reconducir las disposiciones concretas, de modo tal que se ensamblen en un conjunto dotado de sentido". (Derecho justo: fundamentos de ética jurídica. Trad. esp. por Luis Diez-Picazo. Madrid: Civitas, 1985, p. 35).

4 Segundo lições de Humberto Ávila, a denominada dimensão estática da segurança jurídica abrange a cognoscibilidade material do plexo normativo (segurança de existência e de vigência, pela possibilidade de identificação normativa) e a cognoscibilidade intelectual (segurança de conteúdo, pela inteligibilidade normativa) (Teoria da segurança jurídica. 3. ed. São Paulo: Malheiros, 2014, p. 313-14).

${ }_{5} \mathrm{Na}$ perspectiva da necessidade de cognoscibilidade das leis para se propiciar aplicação justa do Direito, Luciano de Camargo Penteado, em lição que merece ser transcrita: "Mesmo em uma perspectiva material da teoria da lei, pode-se notar que esta constitui um guia de orientação à razão prática, um roteiro para a decisão justa, isto é, pautada por uma noção de fim e de bem. Conhecer de modo apropriado as leis que disciplinam um setor do direito é o primeiro passo para poder realiza-lo nos casos concretos a serem decididos. É necessário perceber que há uma finalidade nas mesmas, um direcionamento de fim, uma razão de valor imanente ao texto" (Direito das coisas. 2. ed. São Paulo: Revista dos Tribunais, 2012, p. 46).

${ }^{6}$ A mesma caracterização pode ser encontrada em alguma jurisprudência na caracterização da responsabilidade administrativa por infrações ambientais, que, como cediço, fundamenta-se no poder de polícia (polícia administrativa) e na seara do direito sancionatório. Porém, o objeto de análise do presente trabalho restringe-se à reponsabilidade civil incidente no âmbito do direito ambiental.

7 Cf. CONTADIN, Éder Augusto. Responsabilidade civil ambiental: imprecisões dogmáticas e sistemáticas na jurisprudência brasileira. Portal Direito Ambiental.com - Coluna Direito ambiental em debate. [s.i.]. 2019. Disponível em: htpps://direitoambiental.com/responsabilidade-civil-ambiental-imprecisoes-dogmaticas-esistematicas-na-jurisprudencia-brasileira/. Acesso em: 30 out. 2019.

8 O direito ambiental brasileiro, enquanto ramo do direito dotado de relativa autonomia, comporta subdivisões de função pedagógica, em torno de objetos suficientemente identificáveis. Assim, o direito ambiental florestal 
Analisa-se, no presente trabalho, o acórdão prolatado pelo Tribunal de Justiça de São Paulo, na Apelação Cível no 0056217-64.2012.8.26.0577, da 1aㅡ Câmara Reservada ao Meio Ambiente, cuja relatoria foi do Desembargador Marcelo Berthe, compondo o julgamento os desembargadores Torres de Carvalho e Oswaldo Luiz Palu (d.j.: 07.04.2016).

O julgado tem origem em ação civil pública, de efeitos individuais, ajuizada pelo Ministério Público estadual em face de proprietário de gleba rural com situação ambiental desconforme. Neste aresto, aponta-se a natureza propter rem da obrigação (rectius: dever) de recomposição vegetal de área de Reserva Florestal Legal (RFL) em imóvel onde ela encontrava-se degradada, ainda que tal degradação não tenha sido perpetrada pelo atual proprietário e réu da ação, a qual visa a compeli-lo à recomposição ambiental in natura. A abordagem parece correta, em linha com as premissas lógicosistemáticas vigentes, embora se encontrem na redação da ementa - mais do que no corpo do acórdão - algumas impropriedades terminológicas fruto das confusões dogmáticas mencionadas linhas acima.

Passa-se à análise do aresto do TJSP.

\title{
2. EMENTA E DESENVOLVIMENTO DO JULGADO (FUNDAMENTAÇÃO)
}

O acórdão em análise traz a seguinte ementa, no excerto do que interessa:

"RECURSO DE APELAÇÃO EM AÇÃO CIVIL PÚBLICA. MEIO AMBIENTE. 1. DEMARCAÇÃO DE RESERVA LEGAL. LEI No 12.651/12. Incontroverso nos autos 0 descumprimento de obrigação ambiental de instituição e averbação de reserva legal. 2. RESPONSABILIDADE DO PROPRIETÁRIO. Responsabilidade atual proprietário em promover o reflorestamento da propriedade, ainda que adquirida sem cobertura vegetal. Obrigações de constituição, averbação de reserva legal na matrícula de imóvel e recuperação ambiental que possui natureza propter rem, recaindo sobre o proprietário do imóvel. Imposição de implantação de reversa florestal legal e reparação dos danos ambientais.

Na fundamentação do acórdão, encontram-se as seguintes passagens:

\begin{abstract}
"É incontroverso nos autos que o particular não cumpriu as obrigações ambientais relacionadas à instituição e averbação de reserva legal nos termos previstos nos art. 12 e seguintes do Novo Código Florestal.

"Assim, inexistente qualquer medida voltada à instituição e averbação, nos termos da legislação competente, não há que se falar em regularidade da propriedade.

"Frise-se aqui ser de direito real a natureza da obrigação ambiental que recai sobre o imóvel, propter rem, gravando o bem e transmitindo-se aos proprietários do imóvel. "Portanto, recaindo sobre imóvel obrigação ambiental, impõe-se ao proprietário a sua adequação, independentemente da situação da propriedade à época de sua aquisição ou de ter este efetivamente contribuído para o desmatamento.

"Destarte, irrelevante o fato do imóvel não possuir a condição ambiental mínima prevista na lei ambiental à época de sua aquisição, impondo-se aos proprietários do imóvel a adoção das medidas necessárias à recomposição ambiental de sua
\end{abstract}

concentra o plexo normativo e os institutos jurídicos de proteção e conservação da flora, compatibilizando a utilização e exploração antrópica dos imóveis com os predicados de tutela ambiental. Tem, entre seus marcos legislativos mais importantes, o Código Florestal (Lei ㅇ 12.651/12) e a Lei do Sistema Nacional de Unidades de Conservação (Lei no 9.985/2000). Este sub-ramo por vezes é denominado direito ambiental agrário, por seus institutos se aplicarem mormente na área rural. Porém, pode levar a equívocos, eis que o termo "agrário" se relaciona com especial qualificação de atividade produtiva que, aliás, pode ser desenvolvida em meio urbano. 
propriedade, não havendo, portanto, que se falar em irresponsabilidade ou ônus desmedido a sua reparação".

Ainda, na fundamentação, são colacionados outros acórdãos do mesmo tribunal, corroborando o entendimento esposado. Em um deles, há a transcrição de ementa de acórdão do STJ, da lavra do então Ministro Teori Albino Zawasck, cujos excertos seguem:

\begin{abstract}
“(...) a obrigação de demarcar, averbar e restaurar a área de reserva legal nas propriedades rurais constitui (a) limitação administrativa ao uso da propriedade privada destinada a tutelar o meio ambiente, que deve ser defendido e preservado "para as presentes e futuras gerações" (CF, art. 225). Por ter como fonte a própria lei e por incidir sobre as propriedades em si, (b) configura dever jurídico (obrigação ex lege) que se transfere automaticamente com a transferência do domínio (obrigação propter rem), podendo, em consequência, ser imediatamente exigível do proprietário atual, independentemente de qualquer indagação a respeito de boafé do adquirente ou de outro nexo causal que não o que se estabelece pela titularidade do domínio" (REsp 1.179.316 - STJ - Min. Teori Albino Zavascki)
\end{abstract}

Tanto o acórdão do TJSP, paradigma da presente análise, como os colacionados em sua fundamentação, importam em reação - ou lapidação - à jurisprudência sedimentada principalmente no STJ (com apoio de posições doutrinárias), a qual vislumbra, como visto, um caráter propter rem na responsabilidade civil por danos ambientais.

O acórdão paradigma dessa análise trata como obrigação propter rem o dever do proprietário de imóvel rural proceder à recomposição florística da Reserva Legal Florestal que onera a gleba. A jurisprudência majoritária tende a considerar este mesmo dever como uma obrigação fundada na responsabilidade civil.

É de se notar que o acórdão paradigma dessa análise não está livre de inconsistências. Utiliza a expressão "obrigação propter rem", quando o mais adequado é "dever propter rem". E, como se verá linhas abaixo, não se trata de mero preciosismo terminológico. Embora espécies do gênero situações propter rem, as obrigações e os deveres propter rem diferenciam-se na estrutura e no conteúdo, implicando, por consequência, regimes jurídicos específicos.

Outrossim, e tanto mais grave, o acordão paradigma traz, na parte final de sua ementa, a expressão: "imposição (...) reparação dos danos ambientais". Embora tal expressão apareça descontextualizada do restante da ementa e sem conexão com a fundamentação e com o dispositivo do acórdão (que não fazem alusão alguma à reparação dos danos ambientais ou à aplicação dos preceitos de responsabilidade civil no caso concreto), sua presença é indicativa de resíduos significacionais da posição jurisprudencial que imbrica a responsabilidade civil ambiental a um pretenso caráter proter rem.

\title{
3. INCONSISTÊNCIA DOGMÁTICA DA RESPONSABILIDADE CIVIL AMBIENTAL PROPTER REM
}

Consoante já afirmamos alhures, a responsabilidade civil ambiental possui particularidades que marcam seu regime, porém não a ponto de desnaturar o instituto da responsabilidade civil, 
retirando pressupostos básicos de sua estrutura ou acrescentando elementos que the são incongruentes.

A responsabilidade civil passou por diversos aperfeiçoamentos desde sua consagração pelos códigos modernos (a partir dos códigos racionalistas de fins do século XVIII), aceitando, em paralelo à sua modelagem categorial assente na imputação subjetiva e calcada na noção de delito (ato ilícito), modelagens outras fundadas em critérios objetivos de imputação (notadamente o risco no desenvolvimento de atividades perigosas) e, em casos excepcionais, prescindindo da noção de delito na conformação da antijuridicidade justificadora da obrigação de reparar ${ }^{9}$.

Mas, mesmo na responsabilidade objetiva, onde os fatores de imputação podem variar e podem-se identificar tipos de situações responsivas dentro do enquadramento categorial do instituto da responsabilidade civil, com algumas peculiaridades no regime eficacial, os elementos estruturais e funcionais basilares mantêm-se. Assim também quanto à responsabilidade contratual (ex contractu) em face da responsabilidade aquiliana (ou extracontratual): as pontuais diferenças de regime jurídico não vão ao ponto de desnaturar ou transbordar a categoria jurídica ${ }^{10}$ a que pertencem, qual seja, a responsabilidade civil.

A responsabilidade civil se estrutura em elementos categoriais bem definidos: o agente (pessoa); o dano individualizável e mensurável; o nexo de causalidade; e um fator de imputação, que pode se subjetivo ou objetivo, mas nunca inexistente. Tem por função típica restabelecer a situação anterior ao dano causado, tornando-a indene (ou seja, como se o dano não tivesse ocorrido na esfera jurídica do lesado).

Em seu suporte fático, a responsabilidade civil constitui-se, sempre, de elementos basilares bem definidos: o fato, o dano e a causalidade. Este é seu plano fático. No plano jurídico - que permite fazer recair sobre o agente o dever de reparar o dano causado (imputação do dano) - apresentam-se modelos de controle e justificativa por critérios ora subjetivos, ora objetivos ${ }^{11}$.

O nexo de causalidade é elemento nodal da responsabilidade civil. Em perspectiva jurídica, seu abrandamento pode ser aceito somente de forma excepcional e parcial, recaindo sobre o fato fortuito ${ }^{12}$. O abrandamento das causas de irresponsabilidade - notadamente as excludentes de nexo

\footnotetext{
${ }^{9}$ Cf. MENEZES CORDEIRO, António. Tratado de direito civil: direito das obrigações, Coimbra: Almedina, 2017, v. VIII, p. 287-8. Este autor nomeia as referidas modelagens de responsabilidade civil como, respectivamente, responsabilidade por facto ilícito (ou subjetiva), pelo risco (ou objetiva) e pelo sacrifício. Embora esta última prescinda do pressuposto "ato ilícito" ou "delito", não prescinde da antijuridicidade, deslocada para o prejuízo suportado sem justificação jurídica pela vítima.

10 Para a noção de categoria jurídica, em sentido mais preciso que o de instituto jurídico, cf. ROUBIER, Paul. Théorie générale du droit: historie des doctrines juridiques et philosophie des valeurs sociales. 2. ed. Paris: Librairie du Recueil Sirey, 1951, p. 15-17.

11 Cf. MENEZES CORDEIRO, António. Tratado...cit., p. 318. Na mesma passagem, o referido autor destaca, na análise do plano jurídico da responsabilidade civil: "O modelo monista evoluiu da culpa, enquanto juízo envolvente, capaz de verificar, no agente, a desconformidade da sua conduta exterior com o exigido pelo Direito e a censurabilidade dessa desconformidade; o modelo dualista procede, em instâncias separadas, a um juízo de actuação desconforme (ilicitude) e ao juízo de censurabilidade (culpa em sentido mais estrito ou, rectius, diverso). A diferenciação é conceitual e não, apenas, linguística".

12 Das causas de exclusão de responsabilidade por quebra do nexo causal, o fato fortuito apresenta-se como a figura mais polêmica, densa e rica de abordagens. Desde o direito romano clássico, o fortuito aparece como fator que deslegitima o surgimento da obrigação reparatória. Com as recepções medievas e a posterior incorporação nos códigos modernos, buscam-se os traços científicos dessa importante figura. Diz o fortuito tanto com a quebra da causalidade quanto com a quebra (ou crise) da imputação do dano. Identifica-se com o acaso, com a obra do
} 
causal - pode causar a desnaturação da responsabilidade civil, transmudando-se em seguro de caráter geral ou em forma de garantia ex lege. Por isso, nos ordenamentos modernos, o nexo de causalidade é posto em relevo como pressuposto lógico e estrutural das obrigações de reparação civil, estando sempre ativas as excludentes de causalidade formatadas na culpa exclusiva da vítima, fato de terceiro (em análise de causalidade adequada e eficiente) e a força maior (enquanto fato irresistível e inevitável).

Na responsabilidade civil (contratual ou extracontratual) de imputação subjetiva, o elemento culpa aparece como realce da causalidade. De forma que se a vítima comprova o agir descuidado ou proposital do indigitado autor do dano, a causalidade se estabelece em presunção relativa, desde que o agir culposo esteja em ordem de evidência com o resultado danoso.

Na responsabilidade civil objetiva, o nexo causal é a viga mestra de sua estrutura pois, ante a irrelevância da culpa enquanto fator de imputação, a causalidade assume o papel principal de aferição do elo de ligação entre $o$ fato ou $o$ ato prejudicial e 0 dano perpetrado ${ }^{13}$.

Nos deveres e obrigações propter rem, a causalidade por danos não se coloca ou, quando muito, aparece em termos diversos e secundários, assumindo diversas estrutura e função.

As situações jurídicas propter rem ${ }^{14}$ afiguram-se como deveres jurídicos de causa real, adstringindo o titular de uma situação de direito das coisas - e tão somente enquanto ostente tal titularidade - a um comportamento de direito positivo frente a um dado credor. Estabelece-se estreita vinculação entre a titularidade de uma situação de direito real e a obrigação desencadeada ${ }^{15}$.

destino. Se, durante a pesquisa causal e valorativa não se consegue imputar o dano a ninguém, passa a ser atribuído ao acaso, a um acontecimento irresistível, indomável, por vezes inexplicável, uma causa desconhecida. Modernamente, tem-se o fortuito mais próximo à força maior, como fatos necessários, cujos efeitos são inevitáveis, por vezes imprevisíveis. Porém, seu conceito ainda permanece algo fluido, carente de maior precisão dogmática.

Esse estado de coisas reflete-se na bifurcação do fortuito em duas concepções que encontram grande acolhida e que dividem em dois grupos de aderentes um vasto rol de consagrados autores: a concepção objetiva e a concepção subjetiva.

A concepção subjetiva aproxima-se da análise da conduta do agente, retirando-lhe o nexo de causalidade eficiente com o dano se a conduta do indigitado agente parece escorreita. Relaciona o fortuito com a ausência de culpa, na célebre afirmação, assaz pronunciada, de que o fortuito começa onde termina a culpa. A concepção objetiva procede a uma análise que prescinde de qualquer situação pessoal ou anímica do suposto agente.

Por conta desse dualismo de concepções, somado à influência da concepção subjetiva, tem-se que o fortuito acaba por ser a única causa de exclusão da responsabilidade (por quebra causal) a ser abrandada ou desconsiderada em determinados regimes legais de responsabilidade com imputação objetiva. Para maiores digressões e aprofundamentos sobre o tema, cf. PAULA, Carolina Bellini Arantes de. As excludentes de responsabilidade civil objetiva. São Paulo: Atlas, 2007, p. 90-99 e a obra de FONSECA, Arnoldo Medeiros da. Caso fortuito e teoria da imprevisão. 3. ed. Rio de Janeiro: Forense, 1958, especialmente, p. 80-105.

13 PAULA, Carolina Bellini Arantes de. As excludentes de responsabilidade civil objetiva..., p. 43. Na mesma passagem, a referida autora expressa: "De fato, a responsabilidade civil objetiva só pode ser imputada ao agente se o fato que gerou o dano puder ser a ele atribuído, podendo, até mesmo, ser resultante da atuação de pessoas por quem ele seja responsável ou fato de coisas ou animais a ele pertencentes. Desta forma, a causa da responsabilidade civil objetiva passa a ser a razão desta. Trata-se de tema capital em tal seara da responsabilidade civil". Na mesma p. 43, a referida autora, em nota de rodapé $n^{\circ} 93$, transcreve lição balizadora de Georges Ripert: "De fato, Georges Ripert afirma: 'Se se faz desaparecer a ideia de falta, a ideia de causalidade passa para o primeiro plano, tomando a seu cargo a ideia de responsabilidade. $O$ ato humano traz consigo os seus riscos como uma consequência necessária"' (citação referenciada pela autora, como extraída de: RIPERT, Georges. A regra moral nas obrigações civis. Trad. 3. ed. francesa por Osório de Oliveira. Campinas: Bookseller, 2002, p. 213).

14 Também são denominadas, na doutrina brasileira e estrangeira, de obrigações ob rem e obrigações reais.

15 Cf. Luciano de CAMARGO PENTEADO, Luciano de. Direito das coisas. 2. ed. São Paulo: Revista dos Tribunais, 2012, p. 129. O Prof. José de Oliveira Ascensão enquadra as obrigações propter rem dentre as 
Como assevera José de Oliveira ASCENSÃO, na obrigação propter rem, "a individualidade do sujeito obrigado esbate-se, ao ponto de dever ser sempre determinado mediatamente. Não interessam características pessoais, mas a circunstância de ele ser, nesse momento, o titular daquele direito real" a que a obrigação se conecta ${ }^{16}$.

Portanto, seu pressuposto (ou causa eficiente próxima) não é um ato ilícito ou uma atividade perigosa, mas a titularidade de dado direito real, do qual exsurge a obrigação na circunstância concreta. Assim, os deveres condominiais, seja no condomínio tradicional, seja no edilício (em que se inserem as sempre lembradas dívidas pelas despesas dos condomínios de edifícios); os impostos incidentes pelo fato da propriedade (IPTU, IPVA etc); grande parte dos direitos de vizinhança ${ }^{17}$.

Assim, quando a referida jurisprudência dominante, contraposta ao conteúdo do acórdão do TJSP que estamos a analisar, qualifica a responsabilidade civil ambiental como propter rem, está a confluenciar dois institutos jurídicos que têm pressupostos muito diferentes e não diretamente conectáveis.

Cabe aqui - antes de continuarmos a análise comparativa e distintiva entre a responsabilidade civil e as situações propter rem - proceder a uma caracterização importante, muitas vezes despercebida ou não enfrentada pelos manuais brasileiros, mesmo os mais densos. Dentro do gênero situações propter rem, encontramos as espécies obrigações proter rem e deveres propter rem. As primeiras, estruturam-se como relação obrigacional vulgar, ou seja, como uma relação do tipo creditícia, conformando-se em uma prestação determinável envolvendo sujeitos determinados no momento da execução ${ }^{18}$; os segundos, estruturam-se como deveres de origem ex lege, de caráter geral e de significado coletivo, embora em variegados matizes.

José de Oliveira Ascensão as qualifica como situações jurídicas propter rem não integradas em relação jurídica ${ }^{19}$. Podem também ser nominadas de obrigações propter rem em sentido amplo, ou, ainda, de deveres propter rem. Assim o é por manterem traços característicos do regime das obrigações propter rem em sentido estrito: ligam-se à titularidade do direito real sobre a coisa afetada ao dever, extinguem-se com o abandono liberatório e transmitem-se com a transferência do direito real sobre a coisa.

No ordenamento brasileiro, são exemplos de deveres propter rem: a obrigação do titular do direito de propriedade sobre imóvel rural proceder à recomposição das APP e da Reserva Florestal

relações jurídicas cujos sujeitos são qualificados pela titularidade de direitos reais (Direito civil: reais. 5. ed. Coimbra: Coimbra Editora, 2012, p. 233).

${ }^{16}$ ASCENSÃO, José de Oliveira. Direito civil: reais. 5. ed. Coimbra: Coimbra Editora, 2012, p. 233-4.

17 Registra-se alguma divergência na doutrina acerca da caracterização dos deveres de vizinhança - ou de alguns desses deveres, já que portadores de certa heterogeneidade - como deveres propter rem. Para síntese da polêmica envolvendo a posição de Pontes de Miranda, cf. BUNAZAR, Maurício. Obrigação propter rem: aspectos teóricos e práticos. São Paulo: Atlas, 2014, p. 47-51.

18 Na precisa lição de Luis Díez-Picazo e Antonio Gullón: "Las obligaciones propter rem son las que generan cargo del obligado un auténtico deber de prestación, como cualquier otra relación obligatoria. Su particularidad se halla fundamentalmente en que el sujeto pasivo de esa obligación se individualiza por su posición jurídica: titular de un derecho real sobre una cosa (dominio o ius in re aliena)" (Sistema de derecho civil. 7. ed. Madrid: Tecnos, 2002, v. III, p. 40).

$19 \mathrm{O}$ referido autor classifica as situações propter rem em quatro modalidades, sendo a primeira "a situação propter rem que não está integrada em nenhuma relação jurídica. Haverá uma mera restrição por interesse público ou até também, possivelmente, por interesse privado, de um direito, sem que ninguém mais fique directamente relacionado com aquele sujeito" (Direito civil..., p. 234). 
Legal do imóvel agrário, caso se encontrem degradadas, independentemente se foi ele o causador da degradação ${ }^{20}$; dever do proprietário ou possuidor recuperar o solo contaminado ou de minorar as consequências da contaminação, mesmo que tal contaminação tenha sido perpetrada por anteriores donos ou possuidores ${ }^{21}$; dentre outros. Feitas estas ponderações, seguimos com a análise confrontativa dos institutos.

Também na análise da eficácia jurídica, a obrigação derivada da responsabilidade civil (seja contratual, seja aquiliana) em muito se difere da obrigação/dever propter rem, impedindo-lhes a direta associação.

Na responsabilidade civil, a relação obrigacional oriunda do ato ilícito é, a priori, obrigação de fazer ou de dar coisa certa, cujo conteúdo é a reparação in natura ou específica do bem lesado. $\mathrm{Na}$ impossibilidade de tal reparação específica, ou se assim preferirem as partes, a obrigação inicial substitui-se por obrigação de pagar soma em dinheiro. Trata-se de obrigação substitutiva, que será sempre dívida de valor 22 .

A obrigação ou o dever propter rem, por sua vez, pode configurar-se como prestações de fazer, ou de pagar quantia certa. Diferentemente da obrigação nascida da responsabilidade civil, não há possibilidade de ser substituída (obrigação substitutiva pecuniária) por prestação que garanta resultado de adimplemento. Quando a prestação objeto da obrigação for de pagar, poderá ser dívida de valor ou dívida pecuniária, a depender da hipótese concreta.

A obrigação oriunda da responsabilidade civil se extingue, de ordinário, com a reparação do dano (in natura ou por meio do pagamento de indenização substitutiva do bem); mas, por atrelar-se a um ato ilícito, nunca se extingue com a alteração da titularidade do causador do dano sobre algum direito patrimonial, contextualizado na situação fática, de que adveio a responsabilidade civil $^{23}$. Outrossim a obrigação derivada de responsabilidade civil não se transfere a outrem que não seja o causador imediato do dano, a não ser em casos de assunção de dívida (sempre em sua modelagem típica de ato negocial).

\footnotetext{
20 Por expressa previsão do art. $7^{\circ}, \S \S 1^{0}$ e $2^{\circ}$ do Novo Código Florestal (Lei oㅜ 12.651/12). O mesmo dispositivo, em seu $\S 3^{\circ}$, sanciona o não cumprimento de tal dever real, cominando ao atual proprietário restrições de uso do imóvel.

${ }_{21}$ Os meros deveres propter rem (ou obrigações propter rem em sentido amplo) são associados à ideia de passivo ambiental do imóvel, significando as não conformidades da situação do imóvel com a legislação ambiental vigente, que colocam o proprietário ou o possuidor com animus domini na posição jurídica de obrigado a proceder à regularização do imóvel (= torná-lo conforme à legislação vigente). Tal obrigação consiste em dever genérico, eis que não constante de uma relação jurídica com um credor determinado ou determinável. A posição ativa de tal dever é ocupada pelo Estado ou pela coletividade difusa, representada pelos órgãos ou instituições legitimadas à tutela de tal classe de interesses.

${ }_{22}$ Essencial, porém nem sempre percebida, a distinção entre dívidas de valor e dívidas pecuniárias. Na lição de Orlando Gomes, lastreado em Larenz, dívida pecuniária ou de dinheiro é aquela cuja prestação devida é a própria quantidade de moeda, enquanto que na dívida de valor a prestação é referida ao poder aquisitivo da moeda, variando segundo suas oscilações, isto é, "dívida cuja entidade não é comensurada a uma expressão monetária, mas sim ao valor de um bem ou de uma participação, valor que se tratará posteriormente de se exprimir em dinheiro" (GOMES, Orlando. Questões mais recentes de direito privado - pareceres. São Paulo: Saraiva, 1988, p. 118-19).

${ }^{23}$ Assim, o causador de um dano em acidente automobilístico não se livra da obrigação de indenizar em alienando o automóvel que conduzia; tampouco se livra do dever de reparar o dano ex contractu o titular de posição jurídica contratual que a cede a outrem (cessão de contrato).
} 
Já com a situação propter rem - dada a inerência à titularidade da situação de direito real ${ }^{24}$ - é-Ihe da essência que se extinga para o devedor com a perda ou alteração da titularidade do direito real (situação jurídica de direito das coisas). Também por essa inerência, a situação propter rem transmite-se com a transmissão do direito real a que se refere.

Ainda, as situações propter rem são taxativas, ou seja, numerus clausus, característica essa resultante do certo hibridismo com as situações de direito real que lhes marca a estrutura jurídica. Daí a impossibilidade da atividade criativa da autonomia privada se sobrepor à estrita previsão legal das obrigações propter rem²5.

Nesse passo, mesmo se houvesse compatibilidade estrutural e funcional com a responsabilidade civil (e não há, como visto), a obrigação propter rem não poderia participar ou caracterizar a obrigação de indenizar sem que houvesse estrita previsão e conformação por lei.

Vimos, linhas acima, que as situações jurídicas propter rem comportam tanto as obrigações propter rem como deveres da mesma natureza. Estes últimos não se estruturam como relações jurídicas de direito patrimonial. Nascem diretamente de leis que conformam o âmbito de exercício legítimo do direito de propriedade - como, por exemplo, determinações impostas pelo plano diretor do município e pela legislação urbanística decorrente - e outros deveres que se fundamentam, mediatamente, na função social da propriedade ${ }^{26}$.

Essas últimas situações de deveres jurídicos propter rem alimentam certas sutilezas, que possivelmente levaram à equivocada construção jurisprudencial e doutrinária da responsabilidade civil ambiental com efeitos ou caráter real.

Como já visto, as situações jurídicas propter rem nada têm a ver com a obrigação originada de responsabilidade civil, por portarem estruturas genéticas e funções muito diversas e inconciliáveis. A responsabilidade civil propter rem consiste, pois, em teratologia dogmática ${ }^{27}$.

Porém, algumas confusões são previsíveis diante de análises superficiais de alguns deveres propter rem, como os exemplificados linhas acima. Assim o é porque, frequentes vezes, o efeito prático atingido pelo cumprimento de tais deveres se assemelha - ou se aproxima - dos efeitos práticos perseguidos pela responsabilização civil por danos ambientais. Uma análise mais acurada desvela as confusões suscitadas, demonstrando as eficácias jurídicas próprias de cada instituto jurídico e as profundas diferenças que as marcam.

\footnotetext{
${ }^{24}$ No entendimento de parte da doutrina, o atributo da inerência liga-se à coisa de que é objeto o direito real. $O$ raciocínio é válido apenas se tomado por figuração e tendo-se em conta o que se denomina função fiduciária da linguagem (Cf. MOTA PINTO, Carlos Alberto da. Cessão de contrato. São Paulo: Saraiva, 1985, p. 24-28). Em análise mais detida do fenômeno jurídico, porém, tal raciocínio é imperfeito. O fundamento da obrigação propter rem é a titularidade de situação jurídica de direito das coisas, e é a esta que ela adere, de modo a se transmitir com a transmissão dessa titularidade. Neste sentido, cf. CAMARGO PENTEADO, Luciano de. Direito das coisas. 2. ed. São Paulo: Revista dos Tribunais, 2012, p. 129. Em sentido da inerência à coisa, tem-se a passagem de José de Oliveira Ascensão: "As situações jurídicas propter rem são inerentes à coisa que é objecto do direito real. Acompanham-no por isso quando ele se transmite e extingue-se quando ele se extingue" (op. cit., p. 236).

${ }^{25} \mathrm{Na}$ lição de Luciano de Camargo Penteado, "justifica-se o número fechado (das obrigações propter rem) em vista de duas razões básicas. A estrutura do dever de causa real é apta a atingir futuros adquirentes do bem. Não seria conforme ao sistema que terceiro fosse obrigado por ato alheio sem fonte legal autônoma a permitir isto. Seria um caso de ultraeficácia de relação obrigacional, para além das partes contratantes, em prejuízo do sujeito, o que é vedado (op. cit., p. 131).

${ }^{26}$ Assim, também, a figura da Reserva Florestal Legal, prevista e estruturada no Código Florestal (Lei no 12.651/2012) e objeto do acórdão paradigma da presente análise jurisprudencial.
} 
No setor imobiliário, vários dos deveres propter rem incidentes constituem o que se pode denominar de passivos que oneram o imóvel. Ainda que se possa discutir a precisão terminológica dessa ideia (o passivo é do imóvel ou do titular do direito real sobre ele), tem a virtude de ilustrar a situação devedora a que estará adstrito o titular da gleba desconforme. Trata-se de um dever geral (que, obviamente, especifica seu conteúdo em cada caso concreto) do titular do direito real de manter ou restabelecer a situação jurídica do imóvel em plena conformidade com a legislação vigente, seja de cariz privado, seja de natureza pública. Pesa sobre o titular o dever de conformidade do imóvel com a legislação (civil, urbanística, ambiental, sanitária etc.).

Um exemplo auxiliará na confrontação entre passivos ambientais que recaem sobre o imóvel - e que participam da natureza propter rem - e os pressupostos da responsabilidade civil por danos ambientais ${ }^{28}$.

Se uma pessoa adquire a propriedade de um imóvel rural e, ao depois, descobre que parte do imóvel está com o solo contaminado porque o anterior proprietário fez descarte errado de embalagens de agrotóxicos (enterrando-as em uma vala, ao invés de descartá-las em empresas certificadas), ele - o atual proprietário - está obrigado a minorar os efeitos da contaminação, informando aos órgãos de controle competentes e promovendo técnicas adequadas de descontaminação ou de contenção dos contaminantes, conforme o caso. Essa obrigação não decorre de responsabilidade civil, mas, sim, do passivo ambiental do imóvel, cabendo ao atual proprietário eliminá-lo ou minorá-lo. Trata-se de mero dever propter rem.

Por não decorrer de reponsabilidade civil, este dever do atual proprietário segue um regime próprio que em muito se diferencia do regime jurídico da responsabilidade civil. É balizado pelos postulados hermenêuticos da proporcionalidade e da razoabilidade, assim como pelos princípios da segurança jurídica, da boa-fé e da proibição de empobrecimento sem causa ${ }^{29}$. Assim, o dever de descontaminação total do solo não será exigível do atual proprietário se o valor a ser despendido para essa tarefa for desproporcional em relação ao valor do imóvel ou ao valor de aquisição. Também deverá ser modulado, se o atual proprietário adquiriu o imóvel desconhecendo a situação de contaminação (passivo ambiental oculto) ${ }^{30}$ : poderá ser-lhe exigido o manuseio de técnicas que impeçam o alastramento da contaminação (técnicas de minoração), se razoáveis e levando-se em conta as condições financeiras do obrigado. Obviamente, todas as despesas poderão ser cobradas junto ao anterior proprietário pela via regressiva, mas os riscos de não recebimento sustentam a modulação das despesas a serem arcadas diretamente pelo atual proprietário ${ }^{31}$.

\footnotetext{
${ }^{27}$ CONTADIN, Éder Augusto. Responsabilidade civil ambiental..., passim.

${ }^{28}$ Exemplo que já utilizamos alhures. Cf. CONTADIN, Éder Augusto. Responsabilidade civil ambiental...

${ }^{29}$ Quanto à configuração da proporcionalidade e da razoabilidade como postulados hermenêuticos e quanto à dimensão dinâmica da boa-fé, atrelada à proteção do Estado à confiança legítima na esfera do cidadão, cf. ÁVILA, Humberto. Teoria da segurança jurídica..., p. 649-50; e 353-57, respectivamente.

${ }^{30}$ Quanto às especiais considerações das circunstâncias no dimensionamento e modulação dos deveres do atual proprietário de sanar o passivo ambiental, ver interessante abordagem de Luciano de Camargo Penteado (Direito das coisas..., p. 132, n.r. 62) ao abordar o importante artigo de Carlos Alberto de Salles (Propriedade imobiliária e obrigações propter rem pela recuperação ambiental do solo degradado. Revista de Direito Ambiental, v. 9, n. 34, p. 9-19, abr./jun. 2004).

${ }^{31}$ Essa via regressiva não se dá com fundamento em solidariedade, inexistente no caso, mas, sim, pela via do enriquecimento sem causa. Trata-se, pois, de ação in rem verso.
} 
Ainda por não se tratar de responsabilidade civil - claramente não há nexo causal entre o dano causado e o atual proprietário - não há como haver condenação do atual proprietário em danos morais coletivos. Tampouco age sobre ele o mecanismo da prestação substitutiva pecuniária (indenização em dinheiro) em caso de impossibilidade de recomposição in natura do dano ambiental. No exemplo dado, se a descontaminação do solo se mostrar impossível, ou se sua minoração for inviável, não fica o atual proprietário obrigado a sanar o passivo ambiental (obrigação específica impossível) e nem se lhe converterá em indenização pecuniária ${ }^{32}$.

$\mathrm{Na}$ hipótese aventada, a responsabilidade civil se estabelece perante o anterior proprietário, se tiver sido ele o causador do dano de contaminação, ou se tiver concorrido, de forma eficiente, para a atuação dos causadores diretos do dano (imagine-se sua má diligência ao contratar empresa que efetuou o descarte errado no próprio imóvel, ainda que sem o seu conhecimento). Nesse núcleo de pessoas do nosso exemplo é que se configuram o pressuposto do ato ilício e os requisitos da responsabilidade civil (nexo de causalidade adequada, dano e fator de imputação). Assim, para o anterior proprietário - se causador do dano ${ }^{33}$ - pesará a obrigação de reparar o dano ambiental in totum, tornando a situação indene, independentemente de quão vultoso seja o valor a ser despendido para tal solução; ainda, caso a reparação in natura se mostre impossível, o anterior proprietário (causador do dano) estará adstrito à obrigação substitutiva pecuniária (indenização em dinheiro), dimensionada pelo valor dos danos materiais causados ao meio natural ${ }^{34}$. Também estará adstrito a outras verbas de cunho indenizatório frequentemente pleiteadas em ações de responsabilidade civil ambiental, como é o caso dos danos morais coletivos.

Coloca-se a questão da intersecção dos deveres do anterior e do atual proprietário, lastreados, respectivamente, na responsabilidade civil e no dever propter rem. No nosso exemplo, ambos devem agir sobre a área contaminada, mas por fundamentos diferentes e mediante prestações também juridicamente diversas, embora, em determinadas hipóteses, os efeitos práticos sobre o meio ambiente possam ser semelhantes.

O dever de reparação fundado na responsabilidade civil é independente do dever propter rem cabente ao atual proprietário, de sanar ou de minorar o passivo ambiental do imóvel. Este, para não sofrer outras consequências legais (restrições de financiamentos bancários, multas administrativas, restrições de órgãos ambientais na concessão de novas licenças para as atividades no imóvel etc), estará compelido às obrigações que the cabem de recuperar ou minorar o evento contaminante, independentemente da averiguação da responsabilidade civil pelo anterior proprietário causador do dano, e com os critérios de modulação já expostos. O anterior proprietário (ou possuidor), por sua vez, está compelido à integral reparação do dano ambiental, seja in natura, seja

32 Assim, Maurício Bunazar, estribando-se em lições de Giovanni Balbi: Giovanni Balbi afirma haver certa contradição no fato de um direito subjetivo implicar um dever, e estatui que, para evitar tal contradição, o cumprimento do dever propter rem não pode esvaziar a utilidade do direito real. Disso decorre que o comportamento devido não é qualquer um, mas apenas aquele justificado à luz do exercício do direito real que o ensejou (BUNAZAR, Maurício. Obrigação propter rem..., p. 61).

33 O realce é importante diante das confusões entre responsabilidade civil e obrigação propter rem tratadas no presente artigo: o anterior proprietário responde civilmente pelos danos por ter sido o causador, e não pela mera circunstância de ter sido titular do direito real de propriedade sobre o imóvel, quando da ocorrência do dano. 
por indenização pecuniária, devendo agir sobre a área contaminada mesmo que não seja mais o atual proprietário ou possuidor ${ }^{35}$. $\mathrm{O}$ atual proprietário, caso já tenha agido para descontaminar o solo, poderá cobrar o efetivo causador do dano em ação regressiva in rem verso, a não ser que conhecesse o passivo ambiental (e também sua real extensão) e/ou tenha assumido contratualmente os riscos do passivo.

\section{O DEVER PROPTER REM DE RECOMPOR A RESERVA LEGAL FLORESTAL. ELIMINAÇÃO DO PASSIVO AMBIENTAL DO IMÓVEL. RESPONSABILIDADE CIVIL POR DANOS AMBIENTAIS QUE SE ESTABELECE PERANTE O ANTERIOR TITULAR DO DIREITO DE PROPRIEDADE. INCIDÊNCIA DO REGIME JURÍDICO DOS DEVERES PROPTER REM}

Por todo o exposto, vê-se o acerto da decisão exarada no acórdão sob análise, em congruência sistemática e dogmática com as categorias jurídicas em apreço.

É de se salientar que, atualmente, não mais remanescem dúvidas quanto à natureza de limitação administrativa da Reserva Florestal Legal, assim como de sua estrutura de dever propter rem.

Consoante os ditames do Código Florestal (art. 12 da Lei oㅜ 12.651/12), todo imóvel rural deve manter área com cobertura de vegetação nativa, a título de Reserva Legal, sem prejuízo da aplicação das normas sobre as Áreas de Preservação Permanente, observados os percentuais legais e excetuados os casos previstos no art. 68 do mesmo codex.

Os percentuais do imóvel rural que devem ser destinados para RFL são de 20 a $80 \%$ para a Amazônia Legal e de $20 \%$ para as demais áreas do país.

O art. 68 do Código Florestal traz norma de regularização de situações antropizadas que se consolidaram no tempo sob a égide de legislação menos severa. Trata-se de norma de transição tardia e, portanto, de função corretiva da segurança jurídica. Seus critérios aplicativos ainda estão em discussão nas esferas administrativa e judiciária, pois tal dispositivo legal descuidou de ser mais preciso.

Todo imóvel rural que não tiver o percentual legal da área total da gleba destinado à Reserva Legal, deverá providenciá-lo e florestar tal área, caso não existam remanescentes de vegetação nativa no local e no percentual indicados. Outrossim, se alguém adquiriu a propriedade de imóvel rural em que a Reserva Legal, apesar de formalmente existente, encontra-se degradada, arruinada ou antropizada, deverá proceder à correção ambiental. Todas essas deficiências constituem passivos ambientais do imóvel e estão a cargo do atual titular do direito real.

\footnotetext{
${ }^{34}$ Seguindo-se o disposto no art. 944 do Código Civil, em que a indenização se mede pela extensão do dano, ressalvada a circunstância equitativa do parágrafo único do mesmo artigo.

${ }^{35} \mathrm{Na}$ jurisprudência pátria, costuma-se colocar o problema de o anterior proprietário, causador do dano, não poder pratica atos no imóvel que agora é de outrem, pois não teria mais poderes de ingerência sobre a gleba. Trata-se, data venia, de falso problema. O atual proprietário terá o interesse de que o dano seja solucionado em seu imóvel, pois isso resolverá ou amenizará o passivo ambiental que pesa sobre a coisa. Outrossim, obriga-se em uma relação de cooperação para a reparação do meio ambiente, de modo que, se dificultar ou não franquear o acesso do responsável pelo dano ao imóvel, com o intuito de recuperá-lo, estará, ele mesmo, e a partir desse momento, concorrendo com o ato ilícito.
} 
Não é o atual proprietário devedor de uma obrigação oriunda de responsabilidade civil. O regime jurídico não é esse. Não se responsabilizará em pecúnia se a degradação perpetrada pelo anterior proprietário tornou inviável a reconstituição in natura da vegetação nativa (imagine-se o caso de o dano ter derivado para severa erosão e empobrecimento incorrigível do solo). Este dano incidirá na esfera jurídica de seu causador, ainda que se trate de responsabilidade civil de imputação objetiva que, como visto, não prescinde (mas avulta) do nexo causal.

Por fim, cabe ressaltar que o próprio Código Florestal traça prazos e instrumentos para a regularização do passivo ambiental (Cap. XIII). A desídia do atual proprietário na implementação efetiva da regularização do passivo ambiental poderá adentrar nos pressupostos da responsabilidade civil, uma vez comprovando-se que tal comportamento gerou danos ambientais. Nessa hipótese, surgirá, em paralelo, obrigação de reparação aquiliana dos danos ambientais.

\section{REFERÊNCIAS}

ASCENSÃO, José de Oliveira. Direito civil: reais. 5. ed. Coimbra: Coimbra Editora, 2012.

ÁVILA, Humberto. Teoria da segurança jurídica. 3. ed. São Paulo: Malheiros, 2014.

BUNAZAR, Maurício. Obrigação propter rem: aspectos teóricos e práticos. São Paulo: Atlas, 2014.

CAMARGO PENTEADO, Luciano de. Direito das coisas. 2. ed. São Paulo: Revista dos Tribunais, 2012.

CONTADIN, Éder Augusto. Responsabilidade civil ambiental: imprecisões dogmáticas e sistemáticas na jurisprudência brasileira. Portal Direito Ambiental.com - Coluna Direito ambiental em debate. [s.i.]. 2019. Disponível em: htpps://direitoambiental.com/responsabilidade-civil-ambiental-imprecisoesdogmaticas-e-sistematicas-na-jurisprudencia-brasileira/. Acesso em: 30 out. 2019.

DÍEZ-PICAZO, Luis; GULLÓN, Antonio. Sistema de derecho civil. 7. ed. Madrid: Tecnos, 2002, v. III.

FONSECA, Arnoldo Medeiros da. Caso fortuito e teoria da imprevisão. 3. ed. Rio de Janeiro: Forense, 1958.

GOMES, Orlando. Questões mais recentes de direito privado - pareceres. São Paulo: Saraiva, 1988.

LARENZ, Karl. Derecho justo: fundamentos de ética jurídica. Trad. esp. por Luis Diez-Picazo. Madrid: Civitas, 1985.

MENEZES CORDEIRO, António. Tratado de direito civil: direito das obrigações, Coimbra: Almedina, 2017, v. VIII.

MOTA PINTO, Carlos Alberto da. Cessão de contrato. São Paulo: Saraiva, 1985.

PAULA, Carolina Bellini Arantes de. As excludentes de responsabilidade civil objetiva. São Paulo: Atlas, 2007.

RIPERT, Georges. A regra moral nas obrigações civis. Trad. 3. ed. francesa por Osório de Oliveira. Campinas: Bookseller, 2002.

ROUBIER, Paul. Théorie générale du droit: historie des doctrines juridiques et philosophie des valeurs sociales. 2. ed. Paris: Librairie du Recueil Sirey, 1951. 
SALLES, Carlos Alberto de. Propriedade imobiliária e obrigações propter rem pela recuperação ambiental do solo degradado. Revista de Direito Ambiental, v. 9, n. 34, pp. 9-19, abr./jun. 2004.

Como citar: CONTADIN, Eder Augusto; SOUZA, Eduardo. Dever ambiental propter rem e reponsabilidade civil por dano ambiental - diferenciações necessárias. Revista IBERC, Minas Gerais, v. 2, n. 3, p. 1-14, set./dez. 2019. 